\title{
Epidemiology and Risk Factors of Periodontal Disease
}

\author{
Amin E. Hatem \\ Faculty of Dentistry, Tanta University \\ Egypt
}

\section{Introduction}

Historically, it was believed that all individuals are uniformly susceptible to developing periodontal disease and that accumulation of plaque, poor oral hygiene and perhaps occlusal trauma were sufficient to initiate periodontitis. However, during the past decades it has become accepted that periodontal disease is caused by specific bacterial infection and that individuals are neither uniformly susceptible to these infections nor to the damage caused by them. Study of the distribution of periodontal diseases and their risk factors on a global scale offers a unique investigational model that can assess causation between periodontal diseases and their suspected etiologic risk factors. An understanding of risk factors can lead to theories of causation that will allow clinicians to identify and target individuals susceptible to periodontal disease. This chapter aims to provide a comprehensive overview of the determinants and risk factors of periodontal diseases and how to predict the risk of their occurrence.

\section{Goals of epidemiological studies of periodontal diseases}

Epidemiology is the study of health and disease in populations and the effect of various biologic, demographic, environmental and lifestyles on these states. The essential features of epidemiology as a method of research, when compared to clinical research and case studies, are that 1) groups rather than individuals are the focus of study and 2) persons with and without a particular disease (e.g., periodontal diseases), and with and without the exposure of interest are included, rather than just patients.

The study of population groups rather than individuals allows for valid estimates while accounting for normal biological variation. Broadening a study to include those without disease, as well as those with it, provides a reference point against which to quantify risk. Epidemiologic studies are conducted to describe the health status of populations, elucidate the etiology of diseases, identify risk factors, forecast disease occurrence and assist in disease prevention and control.

\section{Definitions of periodontal disease; Assessment in epidemiological studies}

Epidemiology prerequisite is an accurate definition of periodontal disease. Unfortunately, in periodontal research, uniform criteria have not been yet established. Epidemiological 
studies have employed a wide array of symptoms including gingivitis, probing depths, clinical attachment level scores, and radiographically assessed alveolar bone loss in a particularly inconsistent manner. Considerable variation characterizes the threshold values employed for defining periodontal pockets as "deep" or "pathological," or the clinical attachment level and alveolar bone scores required for assuming that "true" loss of periodontal tissue support has, in fact, occurred. In addition, the number of "affected" tooth surfaces required for assigning an individual subject as a "case;" i.e., as suffering from periodontal disease, varies as well. These inconsistencies in the definitions inevitably affect the figures describing the distribution of the disease.

While the term "periodontal disease" may encompass all pathological conditions of periodontal tissues, gingivitis and periodontitis are used with different meanings. Gingivitis is an inflammatory lesion of marginal gingiva recognized in epidemiologic studies by color change and / or by bleeding on gentle probing within the gingival sulcus or pocket orifice. If loss or destruction of periodontal attachment or alveolar bone occur, the condition is characterized as periodontitis.

\section{Measurement of periodontitis}

The basic clinical measures for periodontitis are clinical attachment loss (CAL) and probing depth (PD). The standard protocol used today for measuring CAL and PD with a manual probe was first described long time ago and has not changed much since (Ramfjord, 1959). Various scaled indexes have been used in the past, but these were "composite" indexes which scored gingivitis and periodontitis on the same scale. Composite indexes are now considered invalid and have thus been discarded.

Although CAL, a measure of accumulated past disease at a site rather than current activity, remains a diagnostic "gold standard" for periodontitis, the absence of consensus on how best to incorporate CAL and PD into a case definition of periodontitis continues to hamper clinical and epidemiological research (Goodson, 1992). A case definition for periodontitis needs to establish 1) what depth of CAL at any one site constitutes evidence of disease processes; 2) how many such sites need to be present in a mouth to establish disease presence; and 3) how to include probing measurements and bleeding on probing (BOP) in the case definition. An approach like the Extent and Severity Index (Carlos et al., 2006), in which "extent" refers to the number of teeth in the mouth with CAL of $\geq 1 \mathrm{~mm}$ and "severity" is the mean CAL for those teeth, might be appropriate in some circumstances. Some consensus on age-related case definitions for "serious" and "moderate" disease would also assist research.

The inherent measurement problems have led researchers to look for markers of periodontitis which, if valid and reliable, would decrease our dependence upon clinical measures based on probing for diagnosing disease. As our understanding of periodontitis etiology has deepened, some markers have emerged as likely candidates. The most promising are the inflammatory cytokines that are expressed in gingival crevicular fluid (GCF) as part of the host response to inflammation, a number of which have been associated with active disease (Page, 1992). These cytokines include prostaglandin E2 (PGE2), tumor necrosis factor-alpha (TNF- $\alpha$ ), IL-1 alpha (IL-1 $\alpha)$, IL-1 beta (IL-1 $\beta$ ), and others. While it has been documented for some time that these and other constituents of GCF are associated with inflammatory response, actually quantifying these associations and determining the sensitivity of the measures is proving more difficult. 


\section{Periodontal disease trends}

There is no globally accepted method for measurement of periodontal disease. Therefore, it is difficult to document changing patterns of periodontal disease over time periods. Nevertheless, during the last 40 years some evidence has accumulated of changes in the occurrence of gingivitis in developed countries. By repeating cross-sectional studies of the same age range using the same survey criteria, Anderson, 1981 reported a decline in gingivitis and improvement in dental cleanliness between 1963 and 1978 among 12-year-old children in England; and Cutress, 1986 reported a decline in prevalence of gingivitis between 1976 and 1982 in the 15- to 19-year age group in New Zealand from 98\% of subjects and $51 \%$ of teeth to $79 \%$ of subjects and $34 \%$ of teeth.

By contrast, Curilovic et al. , 1977 found that, in Zurich, between 1957 and 1975, the prevalence of gingivitis in 7- to 17- year-old children was unchanged and its severity had increased. Moreover, between 1983 and 1993 gingival health and dental cleanliness in 5- to 15- year-old children in the United Kingdom deteriorated: the age-related subject prevalence of gingivitis increased from $19 \%$ to $53 \%$ in 1983 and from $26 \%$ to $63 \%$ in 1993 (O'Brien, 1994). In a Swedish study, Hugoson et al., 1995 carried out a series of three cross-sectional surveys in 1973, 1983 and 1993 to assess oral hygiene and gingivitis during deciduous, mixed and permanent dentition periods. On each occasion, they obtained random samples of approximately 100 subjects at each of the following age levels: 3, 5, 10, 15 and 20 years. Between 1973 and 1983, there was a substantial improvement in plaque, calculus and gingivitis levels, which were attributed to the introduction in 1974 of new dental health care programs based on prevention. However, between 1983 and 1993, the improvement in plaque levels and gingivitis was reversed, suggesting perhaps that the dramatic reduction in childhood caries between 1973 and 1983 had made children, parents and dental personnel complacent about dental health and oral hygiene. It has not so far been possible to demonstrate improvements in periodontitis in children and adolescents, but this is hardly surprising since it is unusual to find significant amounts of periodontal destruction in these age groups. One study, for instance, found no difference in the prevalence of marginal bone loss in a survey of bitewing radiographs from 2 cohorts of 16-year-old adolescents in 1975 and 1988 (Källestål et al., 1991). At both time periods, bone loss affected only 3.5\% of subjects.

\section{Determinants of periodontitis}

Advances in research over recent years have led to a fundamental change in our understanding of the periodontal diseases. As recently as the mid-1960s, the prevailing model for the epidemiology of periodontal diseases included these precepts: 1) all individuals were considered more or less equally susceptible to severe periodontitis; 2) gingivitis usually progressed to periodontitis with consequent loss of bony support and eventually loss of teeth; and 3) susceptibility to periodontitis increased with age and was the main cause of tooth loss after age 35 (Kreshover \& Russell, 1958; Russell, 1967). Advances in our understanding of periodontal diseases since that time have led to the concept of individual periodontal disease susceptibility and reevaluation of this old general susceptibility model.

A risk factor can be defined as an occurrence or characteristic that has been associated with the increased rate of a subsequently occurring disease. It is important to make the 
distinction that risk factors are associated with a disease but do not necessarily cause the disease. Risk factors may be modifiable or non-modifiable. Modifiable risk factors are usually environmental or behavioral in nature whereas non modifiable risk factors are usually intrinsic to the individual and therefore not easily changed. Non modifiable risk factors are also known as determinants. Evidence used to identify risk factors usually is derived from the following types of studies in order of increasing strength of evidence: case reports, case series, case-control study, cross-sectional studies, longitudinal cohort studies, and controlled clinical trials, also known as interventional studies. All of these studies can identify factors associated with a disease though they are not equal in strength. The longitudinal study may be capable of identifying a causal relationship. The interventional study gives the strongest evidence of a causal relationship and furthermore can provide evidence of the benefit of eliminating the risk factor. Associations identified through longitudinal and interventional studies are termed risk factors whereas associations, based on the observations of cross-sectional and case controlled studies are termed risk indicators. Thus the term risk factor denotes a greater weight of evidence supporting an association than does the term risk indicator (Thomas et al., 2005).

\subsection{Modifiable risk factors}

\subsubsection{Smoking}

Smoking behaviors have consistently been associated with attachment loss in most studies (Albandar, 2002). Smokers have a significantly higher risk of developing chronic periodontal disease (Grossi et al., 1994; Hyman \& Ried, 2003; Tomar \& Asma, 2000) and show a higher rate of periodontal destruction over time than non-smokers (Bergstrom et a., 2000; Elter et al., 1999). There is a dose-effect relationship between cigarette smoking and the severity of periodontal disease such that heavy smokers and those with a longer history of smoking show more severe tissue loss than light smokers (Tomar \& Asma, 2000).

Generally, studies show that cigarette smoking is associated with a twofold to sevenfold increased risk of having attachment loss compared with nonsmokers, with a more pronounced risk in young smokers (Bergstrom et al., 2000; Bergstrom, 2003). The population risk due to cigarette smoking has been studied in large surveys and it is estimated that in the United States population, approximately $42 \%$ and $11 \%$ of periodontitis cases may be attributed to current and former cigarette smoking, respectively (Tomar \& Asma, 2000). A survey in Brazilian adults estimated that $12 \%$ of periodontitis cases may be attributable to cigarette smoking (Susin et al., 2004). Cigar and pipe smoking have been shown to have detrimental effects on periodontal health similar to those attributed to cigarette smoking (Albandar et al., 2000).

\subsubsection{Diabetes mellitus}

Certain systemic diseases have been associated with an increased risk of attachment loss. Diabetes is a modifiable factor in the sense that though it cannot be cured, it can be controlled. Studies that have examined the relationship between diabetes and periodontitis are heterogeneous in design and aim. Thus, both positive and negative conclusions have been drawn with respect to the relationship between the two diseases. In general, no difference in impact has been determined between type 1 and type 2 diabetes mellitus.

Diabetic parameters examined include glycemic control, duration of disease, presence of other diabetes-associated complications and population studied. Periodontal parameters 
examined have included gingivitis, clinical attachment loss, and alveolar bone loss (Tomar \& Asma, 2000). Studies have shown a relationship between poor glycemic control and periodontal disease parameters (Cutler et al., 1999; Guzman et al., 2003; Tervonen et al., 1994; Tsai et al., 2002). Finally, studies have been done which suggest that poorly controlled diabetics respond less successfully to periodontal therapy relative to well-controlled and non-diabetics (Westfelt et al., 1996; Tervonan \& Karjalainen, 1997).

\subsubsection{Dental plaque and oral hygiene}

Population studies confirm the close relationship between dental plaque and gingivitis that was initially described by Löe et al., 1965 in non population-based studies. Throughout the globe, dental plaque growth and inflammation of gingival tissue are ubiquitous and strongly linked, irrespective of age, gender or racial/ethnic identification. It is clear from global epidemiology data that a less pronounced relationship appears to exist between dental plaque and severe periodontitis. Severe forms of human periodontitis frequently affect only a subset of population groups globally, even though plaque-induced gingivitis and slight to moderate forms of periodontitis are widespread within the same population groups (Albandar, 2002; Baelum \& Scheutz, 2002; Gjermo et al., 2002; Sheiham \& Netuveli, 2002).

While gingivitis parallels the level of oral hygiene in a population, it is by itself a poor predictor of subsequent periodontitis disease activity (Lang et a., 1990). Oral hygiene can favorably influence the ecology of the microbial flora in shallow-to moderate pockets, but it does not affect host response. Oral hygiene alone has little effect on subgingival microflora in deep pockets and personal oral hygiene practices among health professionals have been shown to be unrelated to periodontitis in these individuals (Merchant et al., 2002). The conclusion from older studies, mostly cross-sectional, in populations with poor oral hygiene is that plaque and supragingival calculus accumulations correlate poorly with severe periodontitis (Löe et al., 1992; Okamoto et al., 1988). Results from other well-controlled studies also concluded that the quantity of plaque accumulation was, at best, only weakly correlated with periodontitis (Grossi et al., 1995; Peretz et al., 1993).

Comprehensive oral hygiene programs are effective in preventing or reducing the level of gingival inflammation in children and adults. These programs, however, may not be viable in preventing aggressive periodontitis and it may be difficult to achieve a satisfactory level of oral hygiene in the general population to prevent chronic periodontitis and periodontal tissue loss effectively (Löe et al., 2000; Morris et al., 2001).

\subsubsection{Specific microorganisms}

Although there is sufficient evidence that accumulation and maturation of a plaque biofilm is necessary for the initiation and progression of periodontal diseases, studies show that bacterial species colonizing the gingival pocket play variable roles in the pathogenesis of these diseases and may therefore possess different levels of risk of periodontal tissue loss (Wolff et al., 1994) . Of all of the various microorganisms that colonize the mouth, there are three, Porphyromonas gingivalis (Pg), Tannerella forsythia (Tf), and Actinobacillus actinomycetemcomitans (Aa) have been implicated as etiologic agents in periodontitis.

The presence of periodontal pathogens, though necessary to cause disease, is not sufficient. Indeed the odds ratio of developing periodontal disease in an individual who harbors one of the putative periodontal pathogens is not high enough to consider them a risk factor (Ezzo 
\& Cutler, 2003). The presence of A. actinomycetemcomitans confers no additional risk of developing localized aggressive periodontitis in adults despite the fact that its presence is necessary for the disease to develop (Buchmann et al., 2000). It has been shown that Prevotella intermedia, $\mathrm{P}$ gingivalis, and Fusobacterium nucleatum may be risk indicators for periodontal disease in a diverse population, though they are not risk factors (Alpagot et al., 1996). Active infections with human cytomegalovirus and other herpesviruses have been proposed as possible risk factors for destructive periodontal diseases, including chronic periodontitis, aggressive periodontitis, and necrotizing periodontal diseases (Kamma \& Slots, 2003). One study found that presence of herpesviruses in subgingival sites was associated with subgingival colonization of these sites with periodontopathic bacteria and with a threefold to fivefold increased risk of severe chronic periodontitis (Contreras et al., 1999).

While these organisms in the periodontal crevice are closely associated with periodontitis, an important finding is that supragingival plaque can serve as a natural reservoir for them (Sakellari et al., 2001). When the bacterial insult is strong enough to overwhelm host defense, bacteria in supragingival plaque migrate subgingivally to form a subgingival biofilm. Frequent professional supragingival cleaning, added to good personal oral hygiene, has been shown to have a beneficial effect on subgingival microbiota in moderately deep pockets (Hellstrom et al., 1996). These findings collectively form an evidence base for close control of supragingival plaque as part of periodontal therapy.

\subsubsection{Psychological factors}

Studies have demonstrated that individuals under psychological stress are more likely to develop clinical attachment loss and loss of alveolar bone (Hugoson et al., 2002; Pistorius et al., 2002; Wimmer et al., 2002). One possible link in this regard may be increases in production of IL-6 in response to increased psychological stress (Kiecolt- Glaser et al., 2003). Another study suggests that host response to P. gingivalis infection may be compromised in psychologically stressed individuals (Houri Haddad et al., 2003).

Despite existing evidence from case control and cross sectional studies, no longitudinal or interventional studies have been published that confirm psychological stress as a risk factor for periodontal disease. Perhaps the relationship is simply due to the fact that individuals under stress are less likely to perform regular good oral hygiene and prophylaxis (Croucher et al., 1997).

\subsubsection{Obesity}

Obesity is one of the most significant health risks of modern society, and is now recognized as a major health concern in both developed and developing countries (Doll et al., 2002). The prevalence of obesity is increasing at alarming rates, approaching epidemic proportions, particularly among children and young adults (Freidmn, 2000). Obesity itself has been recognized as a risk factor for numerous adult diseases, and may be a factor in the incidence of periodontitis.

Body mass index (BMI) (Elter et al., 2000; Grossi \& Ho 2000), waist-to-hip circumference ratio (WHR) and body fat, (Saito et al., 1998; 2000, 2001) may be factors in the incidence of periodontal disease. Conditions associated with obesity, e.g. "the metabolic syndrome", a clustering of dyslipidemia and insulin resistance may exacerbate periodontitis (Grossi \& Ho, 2000). Long-term interest in the role of nutrition and periodontal disease questions the role of nutrients in periodontal disease pathogenesis. Recently, an association between obesity 
and periodontal disease has been suggested (Amin, 2010). Furthermore, the results of the Third National Health and Nutrition Examination Survey conducted in the United States of America showed that waist to hip ratio, body mass index (BMI), fat free mass and log sum subcutaneous fat were significantly correlated to periodontitis, signifying that abnormal fat metabolism may be an important factor in the pathogenesis of periodontal diseases (wood et al., 2003). It has been proposed that the patterns of fat distribution and its relation to periodontal pathogenesis follow those observed with other obesity-related health problems, such as hypertension and type II diabetes, where visceral fat accumulation plays a key role in increasing susceptibility to these diseases (wood et al., 2003).

Obesity has been postulated to reduce blood flow to the periodontal tissues, promoting the development of periodontal disease (Shuldiner et al., 2001). Furthermore, obesity may enhance immunological or inflammatory disorders, which might be the reason obese subjects tend to exhibit escalating poor periodontal status relative to non-obese individuals (Nishida et al., 2005).

A proposed model linking obesity and periodontal infection suggested that insulin resistance mediates the relationship between them. Dietary free fatty acids contribute not only to obesity but also to insulin resistance by enhancing destruction of $\beta$ cells of the pancreas (Saiti et al., 1999). Insulin resistance, in turn, contributes to a generalized hyperinflammatory state, including periodontal tissue, especially when triggered by oral pathogens. Furthermore, adipocytokines, which include tumor necrosis factor a (TNF-a) secreted by adipose tissues, appear to be directly related to periodontal destruction (Nishida et al., 2005). On the other hand, There is some evidence that cytokines such as interleukin-1 $\beta$ (IL-1- $\beta$ ) and interferon $\gamma$ and Gram negative lipopolysaccharides that are produced in high quantities in response to periodontal infection may interfere with lipid metabolism (wood et al., 2003). This may further enhance obesity and obesity-related health problems.

\subsubsection{Socioeconomic status (SES)}

Multitudes of disease conditions are associated with socioeconomic status, and cause/effect is plausible. Generally, those who are better educated, wealthier, and live in more desirable circumstances enjoy better health status than the less educated and poorer segments of society. Periodontal diseases are no different and have been related to lower SES (Astrom \& Rise, 2001; Thomson \& Locker , 2000). The ill effects of living in deprived circumstances can start early in life (Schou \& Wight, 1994). Gingivitis and poor oral hygiene are clearly related to lower SES, but the relationship between periodontitis and SES is less direct. On the other hand, CAL of $\geq 4 \mathrm{~mm}$ and $\geq 7 \mathrm{~mm}$ in at least one site were both closely correlated with educational levels (Bethesda, 1987).

It is likely that the widely observed relation between SES levels and gingival health is a function of better oral hygiene among the better educated and a greater frequency of dental visits among the more dentally aware. While racial/ethnic differences in periodontal status have been demonstrated many times, it is thought unlikely that these represent true genetic differences. It is more likely that SES, a complex and multifaceted variable that can include a variety of cultural factors, is confounding these relationships.

\subsection{Non-modifiable risk factors 6.2.1 Genetic factors}

Although bacterial infection is the etiologic agent in periodontal disease, studies of identical twins suggest $50 \%$ of susceptibility to periodontal disease is due to host factors 
(Michalowicz et al., 2000). Similarly, indigenous and relatively isolated populations have been shown to develop distinct periodontal disease that differ from group to group (Dowsett et al., 2001). Several gene polymorphisms have been investigated, some of which have been shown to be associated with an increased risk of periodontitis ( $\mathrm{Li}$ et al., 2004; Noack et al., 2004). Various genetic risk factors, however, may explain only a part of the variance in the occurrence of periodontitis (Diehl et al., 1999). In addition, significant interactions seem to exist between genetic, environmental, and demographic factors (Albandar \& Rams).

Most of the research relating to the strength of genetics as a determinant of disease has been laboratory and clinical studies rather than epidemiology, but that research should still be briefly reviewed here. The original 1997 report, using data from patients in private practices, found that a specific genotype of the polymorphic IL-1 gene cluster was associated with more severe periodontitis (Kornman et al., 1997). This relationship could be demonstrated only in non-smokers, which suggested right away that the genetic factor was not as strong a risk factor as smoking. The IL-1 gene cluster has received a lot of research attention since then. This is appropriate, given that the proinflammatory cytokine IL-1 is a key regulator of the host response to microbial infection, although IL-1 is unlikely to be the only genetic factor involved (Mark et al., 2000; McDevitt et al., 2000). IL-1 has been identified as a contributory cause of periodontitis in one epidemiological study (Thomson et al., 2001).

While there seems to be little doubt about a genetic component in periodontitis, the strength of that component is still being determined. At one end, a study among 169 twin pairs concluded that about half of the variance in periodontitis was attributable to heritability (Michalowicz et al., 2000). A combination of IL-1 genotyping and smoking history may provide a good risk profile for patients (McDevitt et al., 2000) and a smoking-genetic interaction may be a contributory factor in severity of periodontitis. The role of IL-1 in regulating host response to infection has been described as clearly present, but not essential (Cullinan et al., 2001). Further research, especially epidemiological studies of people with and without disease, will be necessary before the genetic contribution to the initiation and progression of periodontitis can be specified.

\subsubsection{Aging}

Ageing is associated with an increased incidence of periodontal disease (Grossi et al., 1994; Grossi et al., 1995). However it has been suggested that the increased level of periodontal destruction observed with aging is the result of cumulative destruction rather than a result of increased rates of destruction. The older assumption that periodontitis is a disease of aging is no longer tenable (Burt, 1994). The current view sees the greater periodontal destruction in the elderly as reflecting lifetime disease accumulation rather than anespecific condition.

A relatively low prevalence of severe (as opposed to moderate) CAL among the elderly was first shown in Sweden and has since been demonstrated elsewhere (Hugoson \& Jordan, 1982). Surveys of older people in the United States, Canada, and Australia have found that CAL or PD of $6 \mathrm{~mm}$ or more was prevalent in 15\% to $30 \%$ of persons examined (Hunt et al., 1990; Locker \& Leake, 1993). In all of these studies, CAL of 4 to $6 \mathrm{~mm}$ was common. Higher estimates of periodontal destruction came from a cross sectional New England study of community-living elderly people (Fox et al., 1994). All of these reports agree that CAL increases with age, but most did not find extensive loss of function in the affected teeth. 
It can be hypothesized that the more susceptible members of the population are those in whom periodontitis begins in youth. If that is so, then the relatively low prevalence of severe CAL among many dentate elderly could be partly a survival phenomenon, meaning that those most susceptible to severe periodontitis have already lost teeth. The most rapid disease progression is seen in that relatively small number of persons in whom the disease starts young, and there is some evidence that these individuals have some genetic predisposition to periodontitis (Parkhill et al., 2000; Thomson et al., 2001). It is uncommon for elderly people with reasonably intact dentition to exhibit sudden bursts of periodontitis. Tooth retention, good oral hygiene, and periodontal health are closely associated, regardless of age (Abdellatif \&, Burt, 1987).

\subsubsection{Gender}

Several studies also show an association between gender and attachment loss in adults, with men having higher prevalence and severity of periodontal destruction than women (Albandar, 2000; Morris et al., 2001). Data suggest that this finding may be related to genderdependent genetic predisposing factors or other sociobehavioral factors (Reichert et al., 2002).

These gender differences have not been explored in detail, but are thought to be more related to poorer oral hygiene, less positive attitudes toward oral health, and dental-visit behavior among males than to any genetic factor. There are, of course, certain genderrelated temporary syndromes related to hormonal conditions, such as pregnancy-associated gingivitis, as well as puberty-associated gingivitis which can affect children of both sexes (Albandar, 2005).

\subsubsection{Ethnicity}

The level of attachment loss is also influenced by race/ethnicity, although the exact role of this factor is not fully understood. Certain racial/ethnic groups, particularly subjects of African and Latin American background, have a higher risk of developing periodontal tissue loss than other groups. In the United States population, subjects of African or Mexican heritage have greater attachment loss than Caucasians (Albandar et al., 1999).

The association of periodontal disease with race/ethnicity is significantly attenuated when certain effects such as cigarette smoking and income are accounted for (Hyman \& Reid, 2003). This effect modification suggests that certain racial/ethnic characteristics are indicators of or confounded by certain other effects. For instance, African Americans generally have lower socioeconomic status than Caucasians. Hence, the increased risk of periodontitis in certain racial/ethnic groups may be partly attributed to socioeconomic, behavioral, and other disparities (Poulton et al., 2002). On the other hand, there is evidence that increased risk may also be partly related to biologic/genetic predisposition (Albandar et al., 2002; Haubek et al., 2002).

\section{Predicting the risk of periodontitis}

Attempts to identify markers for future disease go back some years. The aim is to identify the presence of some easily measured entities that clinicians can readily test for in a patient that would predict with high reliability the risk for future disease. The presence of visible plaque and calculus, as one example of a hypothesized marker, was long assumed to predict 
future CAL or bone loss, but studies have shown that clinical measures of plaque and calculus by themselves do not predict future disease to any useful extent (Badersten et al., 1990; Persson et al., 1998). Models that have included the subgingival presence of specific pathogens such as $\mathrm{Aa}, \mathrm{Pg}$, and $\mathrm{Tf}$ with other indicators have shown a moderate degree of predictability (Timmerman et al., 2001; Tran et al., 2001).

Host response needs to be worked into the equation, and it is now recognized that smoking and genetic predisposition are major players in this regard. When smoking and IL-1 genotype status are included in a predictive model, none of the baseline clinical indicators added significantly to the model for subsequent tooth loss. The baseline clinical indicators performed much better in a model that included IL-1 genotype status in non-smokers (McGuire \& Nunn, 1999).

Studies have investigated the role of psychosocial stress in terms of adverse life events or a history of clinical depression. Stress does seem to be associated with progressive periodontitis, whether assessed in a case-control study, cross-sectionally, or in a longitudinal design (Croucher et al., 1997; Elter et al., 1999; Genco et al., 1999). Since psychosocial distress is a well-documented risk factor for a number of different diseases, the identification of its predictive role in periodontitis strengthens the hypothesis that periodontitis is related to systemic diseases.

While risk prediction is still not a precise science in periodontology, enough advances in our knowledge of risk factors have been made to permit development of a risk calculator that is offered to practitioners to help assess a patient's risk of disease (Page et al., 2002). Refinement of risk prediction models in the future will give practitioners an ever improving evidence base upon which to select treatment.

\section{Periodontal disease as a risk factor for other diseases}

The possible role of periodontal infections as risk factors for systemic diseases has recently attracted special attention. Heart disease has been reported to be the condition most commonly found in Periodontitis patients (Umino \& Nagao, 1993). DeStefano et al., 1993 reported that subjects with Periodontitis had a $25 \%$ increased risk for coronary heart disease (CHD) when compared to periodontitis-free individuals. Among men younger than 50 years of age at baseline, subjects with Periodontitis were $70 \%$ more likely to develop CHD than men without periodontal disease.

Loesche, 1994 reported that periodontal infections induce low-level bacteraemia, elevated white blood cell counts, and exposure of the host to endotoxins that may affect endothelial integrity, metabolism of plasma lipoproteins, platelet function and blood coagulation. Robert et al., 2002 concluded that, the accumulation of epidemiologic, in vitro, clinical and animal evidence suggests that periodontal infection may be a contributing risk factor for heart disease. However, legitimate concerns have arisen about the nature of this relationship.

Periodontal infections as a risk factor for pre-term low birth weight (PLBW) were discussed in a report by Offenbacher et al., 1996. The authors studied pregnancy outcome and a broad array of putative risk factors in 124 mothers and revealed that the adjusted odds ratio for PLBW for women with severe periodontal disease was 7.5. Interestingly, an attributable risk analysis indicated that as much as $18 \%$ of all PLBW cases could be due to periodontal infections. These data gain in credibility bearing in mind that experimental studies in rats have verified occurrence of PLBW among animals subjected to experimental Periodontitis (Collin et al., 1994a, 1994b). 


\section{References}

Abdellatif, HM. \& Burt, BA. (1987). An epidemiological investigation into the relative importance of age and oral hygiene status as determinants of periodontitis. Journal of Dental Research, Vol.66, pp. 13-18, ISSN 1544-0591

Albandar, JM.; Brunelle, JA. \& Kingman, A. (1999). Destructive periodontal disease in adults 30 years of age and older in the United State. Journal of Periodontology, Vol.70, No.1, pp. 13-29, ISSN 0022-3492

Albandar, JM.; Streckfus, CF. \& Adesanya, MR. (2000). Cigar, pipe, and cigarette smoking as risk factors for periodontal disease and tooth loss. Journal of Periodontology, Vol.71, No.12 pp. 1874-1881, ISSN 0022-3492

Albandar, JM. (2000). Global risk factors and risk indicators for periodontal diseases. Periodontology 2000, Vol. 29, pp. 177-206, ISSN 0906-6713

Albandar, JM. (2002). Global risk factors and risk indicators for periodontal diseases. Periodontology 2000, Vol. 29, pp. 177-206, ISSN 0906-6713

Albandar, JM. \& Rams, TE. (2002). Risk factors for periodontitis in children and young persons. Periodontology 2000, Vol.29, pp. 207-222, ISSN 0906-6713

Albandar, JM.; DeNardin, AM. \& Adesanya, MR. (2002). Associations of serum concentrations of $\operatorname{IgG}, \operatorname{IgA}, \operatorname{IgM}$ and interleukin-1beta with early-onset periodontitis classification and race. Journal of Clinical Periodontology, Vol.29, No.5, pp. 421-426, ISSN 0303-6979

Albandar, JM. (2005). Epidemiology and risk factors of periodontal disease. Dental Clinics of North America, Vol.49, pp. 517-532, ISSN 0011-8532

Alpagot, T.; Wolff, LF.; Smith, QT. \& Trao, SD. (1996). Risk indicators for periodontal disease in a racially diverse urban population. Journal of Clinical Periodontology, Vol.23, pp. 982-988, ISSN 0303-6979

Amin, H. (2010). Relationship between overall and abdominal obesity and periodontal disease among young adults. Eastern Mediterranean Health Journal, Vol.6, No.4 pp. 48, ISSN 1020-3397

Anderson, RJ. (1981). The changes in the dental health of 12-yearold schoolchildren in two Somerset schools. A review after an interval of 15 years. British Dental Journal, Vol.150, pp. 218-221, ISSN 0007-0610

Astrom, AN. \& Rise, J. (2001). Socio-economic differences in patterns of health and oral health behaviour in 25-yearold Norwegians. Clinical Oral Investigation, Vol.5, pp. 122-128, ISSN 1436-3771

Badersten, A.; Nilveus, R. \& Egelberg, J. (1990). Scores of plaque,bleeding, suppuration and probing depth to predictprobing attachment loss. 5 years of observation followingnonsurgical periodontal therapy. Journal of Clinical Periodontology, Vol. 17, pp. 102-107, ISSN 0303-6979

Baelum, V. \& Scheutz, F. (2002). Periodontal diseases in Africa. Periodontology 2000, Vol. 29, pp. 79-103, ISSN 0906-6713

Bergstrom, J.; Eliasson, S. \& Dock, J (2000). A 10-year prospective study of tobacco smoking and periodontal health. Journal of Periodontology, Vol.71, No.8, pp. 1338-1347, ISSN 0022-3492 
Bergstrom, J. (2003). Tobacco smoking and risk for periodontal disease. Journal of Clinical Periodontology, Vol. 30,No2, pp. 107-113, ISSN 0303-6979

Bethesda, MD. (1987). Oral Health of United States Adults. National Institute of Dental Research, NIH publication No. 87, 2868

Buchmann, R.; Muller, RE.; Heinecke, A. \& Lange, DE. (2000). Actinobacillus actinomycetemcomitans in destructive periodontal disease. Three-year follow-up results. Journal of Clinical Periodontology, Vol.71, pp. 444-453, ISSN 0303-6979

Burt, BA. (1994). Periodontitis and aging: Reviewing recent evidence. Journal of the American Dental Association, Vol.125, pp. 273-279, ISSN 0002-8177

Carlos, JP.; Wolfe, MD. \& Kingman, A (1986). The extent and severity index: A simple method for use in epidemiologic studies of periodontal disease. Journal of Clinical Periodontology, Vol.13, pp. 500-505, ISSN 0303-6979

Collins, JG.; Windley, HWr; Arnold, RR. \& Offenbacher, S. (1994) a. Effects of a Porphyromonas gingivalis infection on inflammatory mediator response and pregnancy outcome in hamsters. Infection and Immunity, Vol.62, pp. 4356-4361, ISSN 1098-5522

Collins, JG.; Smith, MA; Arnold, RR. \& Offenbacher, S. (1994) b. Effects of Escherichia coli and Porphyromonas gingivalis lipopolysaccharide on pregnancy outcome in the golden hamster. Infection and Immunity, Vol.62, pp. 4652-4655, ISSN 10985522

Contreras, A.; Umeda, M. \& Chen, C. (1999). Relationship between herpesviruses and adult periodontitis and periodontopathic bacteria. Journal of Periodontology, Vol.70, No.5, pp. 478-484, ISSN 0022-3492

Croucher, R.; Marcenes, WS; Torres, MC.; Hughes, F. \& Sheîham, A. (1997). The relationship between life-events and periodontitis. A case-control study. Journal of Clinical Periodontology, Vol.24, pp. 39-43, ISSN 0303-6979

Cullinan, MP.; Westerman, B. \& Hamlet, SM. (2001). A longitudinal study of interleukin-1 gene polymorphisms and periodontal disease in a general adult population. Journal of Clinical Periodontology, Vol.28, pp. 1137-1144, ISSN 0303-6979

Curilovic, Z.; Mazor, Z. \& Berchtold, H. (1977). Gingivitis in Zurich schoolchildren. A reexamination after 20 years. Schweiz Monatsschr Zahnheikd, Vol.87, pp. 801-808, ISSN 0906-6713

Cutler, CW.; Machen, RL.; Jorwani R. \& Iacopino, AM. (2000). Heightened gingival inflammation and attachment loss in type 2 diabetics with hyperlipidemia. Journal of Clinical Periodontology, Vol.70, pp. 1313-1321, ISSN 0303-6979

Cutress, TW. (1986). Periodontal health and periodontal disease in young people: global epidemiology. International Dental Journal, Vol.36, pp. 146-151, ISSN 00206539

DeStefano, F.; Anda, RF.; Kahn, HS.; Williamson, DF. \& Russell, CM. (1993). Dental disease and risk of coronary heart disease and mortality British Medical Journal, Vol. 306, pp. 688-691, ISSN 0959-8138

Diehl, SR.; Wang, Y. \& Brooks, CN. (1999). Linkage disequilibrium of interleukin-1 genetic polymorphisms with early-onset periodontitis. Journal of Periodontology, Vol.70, No.4 pp. 418-430, ISSN 0022-3492 
Doll, SG.; Paccaud, F \& Bovert, B. (2002). Body mass index, abdominal adiposity and blood pressure: Consistency of their association across developing and developed countries. International Journal of Obesity and Related Metabolic Disorders, Vol.26, pp. 48-57, ISSN 0307-0565

Dowsett, SA.; Archila, I.; Segreto, VA. \& Kowolik, MJ. (2001). Periodontal disease status of an indigenouspopulation of Guatemala, Central America. Journal of Clinical Periodontology, Vol.28, pp. 663-671, ISSN 0303-6979

Elter, JR.; Beck, JD. \& Slade, GD (1999). Etiologic models for incident periodontal attachment loss in older adults. Journal Clinical Periodontology, Vol.26, No.2, pp. 113-23, ISSN 0303-6979

Elter, E.; Williams, R; Champagne, C.; Offenbacher, S. \& Beck, J. (2000). Association of obesity and periodontitis. Journal of Dental Research, Vol.79 (abstract), pp. 625, ISSN 0022-0345

Ezzo, PJ. \& Cutler, CW. (2003). Microorganisms as risk indicators for periodontal disease. Periodontology 2000, Vol.32, pp. 24-35, ISSN 0906-6713

Fox, CH.; Jette, AM.; McGuire \& Feldman, HA. (1994). Periodontal disease among New England elders. Journal of Periodontology, Vol. 65, pp. 676-684

Freidmn, G. (2000). Obesity in the new mellenium. Nature, Vol.404, pp. 632-634, ISSN 00280836

Genco, R.; Ho, AW.; Grossi, SG.; Dunford, RG. \& Tedesco, LA. (1999). Relationship of stress, distress and inadequate coping behaviors to periodontal disease. Journal of Periodontology, Vol. 80, pp. 1700-1703, ISSN 0022-3492

Genco, R.; Offenbacher, S. \& Beck, J. (2002). Periodontal disease and cardiovascular disease. Epidemiology and possible mechanisms. Journal of the American Dental Association, Vol.133, No1, pp. 148-228, ISSN 0002-8177

Gjermo, P.; Rösing, CK; Susin, C. \& Oppermann, R. (2002). Periodontal diseases in South and Central America. Periodontology 2000, Vol. 29, pp. 70-78, ISSN 0906-6713

Goodson, JM. (1992). Diagnosis of periodontitis by physical measurement: Interpretation from episodic disease hypothesis. Journal of Periodontology, Vol.63, (Suppl.), pp. 373382, ISSN 0022-3492

Grossi, SG.; Zambon, JJ. \& Ho, AW (1994). Assessment of risk for periodontal disease. Risk indicators for attachment loss Journal of Periodontology, Vol. 65, No.3 pp. 260-267, ISSN 0022-3492

Grossi, SG.; Genco, R. \& Machtei, EE. (1995). Assessment of risk for periodontal disease. II. Risk indicators for alveolar bone loss. Journal of Periodontology, Vol.66, pp. 23-29, ISSN 0022-3492

Grossi, SG. \& Ho, A. (2000). Obesity, insulin resistance and periodontal disease. Journal of Dental Research, Vol.79 (abstract), pp. 625, ISSN 0022-0345

Guzman, S.; Karima, M.; Wang, HY \& Van Dyke, TE. (2003). Association between interleukin-1 genotype and periodontal disease in a diabetic population. Journal of Periodontology, Vol.74, pp. 1183-1190, ISSN 0022-3492

Haubek, D.; Ennibi, OK. \& Abdellaoui, L. (2002). Attachment loss in Moroccan early onset periodontitis patients and infection with the JP2-type of Actinobacillus actinomycetemcomitans. Journal of Clinical Periodontology, Vol.29, No.7, pp. 657-660, ISSN 0303-6979 
Hellstrom, MK.; Ramberg, P; Krok, L. \& Lindhe, J. (1996). The effect of supragingival plaque control on the subgingival microflora in human periodontitis. Journal of Clinical Periodontology, Vol.23, pp. 934-940, ISSN 0303-6979

Houri-Haddad, Y.; Itzchaki, O; Ben-Nathan, D. \& Shapira, L. (2003). The effect of chronic emotional stress on the humoral immune response to Porphyromonas gingivalis in mice. Journal of Periodontal Research, Vol.38, pp. 204-209, ISSN 0022-3484

Hugoson, A.; Koch, G. ; Bergendal, T. \& Thorstensson, H. (1995). Oral health of individuals aged 3-80 years in Jo"nko"ping, Sweden in 1973, 1983 and 1993. II. Review of clinical and radiographic findings. Swedish Dental Journal, Vol.19, pp. 243-260, ISSN 0347-9994

Hugoson, A.; Ljungquist, B. (2002). The relationship of some negative events and psychological factors to periodontal disease in an adult Swedish population 50 to 80 years, of age. Journal of Clinical Periodontology, Vol.29, pp. 247-253, ISSN 03036979

Hugoson, A. \& Jordan, T. (2003). Frequency distribution of individuals aged 20-70 years according to severity of periodontal disease. Community Dentistry and Oral Epidemiology, Vol. 10, pp. 187-192, ISSN 0301- 5661

Hunt, RJ.; Levy, SM. \& Beck, JD. (1990). The prevalence of periodontal attachment loss in an Iowa population aged 70 and older. Journal of Public Health Dentistry, Vol.50, pp. 251-256, ISSN 0022-4006

Hyman, JJ. \& Reid, BC (2003). Epidemiologic risk factors for periodontal attachment loss among adults in the United States. Journal of Clinical Periodontology, Vol. 30, No.3, pp. 230-237, ISSN 0303-6979

Källestål, C. \& Matsson, L. (1991). Marginal bone loss in 16-year-old Swedish adolescents in 1975 and 1988. Journal of Clinical Periodontology, Vol.18, pp. 740-743, ISSN 0303-6979

Kamma, JJ. \& Slots, J. (2003). Herpesviral-bacterial interactions in aggressive periodontitis. Journal of Clinical Periodontology, Vol.30, No.5, pp. 420-426, ISSN 0303-6979

Kiccolt-Glaser, JK.; Preacher, TKJ; MacCallum, RC.; Arkinson, C. \& Glaser, R. (2003). Chronic stress and age-related increases in the proinflammatory cytokine II-6. Proceedings of the National Academy of Science USA, Vol.100, pp. 9090-9095

Kornman, KS.; Crane, A. \& Wang, HY. (1997). The interleukin-1 genotype as a severity factor in adult periodontal disease. Journal of Clinical Periodontology, Vol.24, pp. 7277, ISSN 0303-6979

Kreshover, SJ. \& Russell AL. (1958). Periodontal disease. Journal of American Dental Association, Vol.56, pp. 625-629, ISSN 0002-8177

Lang, NP.; Adler, R.; Joss, A. \& Nyman, S. (1990). Absence of bleeding on probing. An indicator of periodontal stability. Journal of Clinical Periodontology, Vol.17, pp. 714721, ISSN 0303-6979

Li, Y.; Xu, L. \& Hasturk, H. (2004). Localized aggressive periodontitis is linked to human chromosome 1q25. Human Genetics, Vol.114, No.3, pp. 291-297, ISSN 1432-1203

Locker, D. \& Leake, JL. (1993). Periodontal attachment loss in independently living older adults in Ontario, Canada. Journal of Public Health Dentistry, Vol.53, pp. 6-11, ISSN 0022-4006

Löe, H.; Theilade, E. \& Jensen, SB. (1965). Experimental gingivitis in man. Journal of Periodontology, Vol.36, pp. 177-187, ISSN 0022-3492 
Löe, H.; Anerud, A. \& Boysen, H. (1992). The natural history of periodontal disease in man: Prevalence, severity, and extent of gingival recession. Journal of Periodontology, Vol.63, pp. 489-495, ISSN 0022-3492

Löe, H. (2000). Oral hygiene in the prevention of caries and periodontal disease. International Dental Journal, Vol.50, No.3, pp. 129-39, ISSN 0020-6539

Loesche, WJ. (1994). Periodontal disease as a risk factor for heart disease. Compendium, Vol.25, pp. 976-985, ISSN 1074-3197

Mark, LL.; Haffajee, AD. \& Socransky, SS. (2000). Effect of the interleukin-1 genotype on monocyte IL-1beta expression in subjects with adult periodontitis. Journal of Periodontal Research, Vol. 35, pp. 172-177, ISSN 0022-3484

McDevitt, MJ.; Wang, HY. \& Knobelman, C. (2000). Interleukin-1 genetic association with periodontitis in clinical practice. Journal of Periodontology, Vol.71, pp. 156-163, ISSN 0022-3492

McGuire, MK.; \&Nunn, ME. (1999). Prognosis versus actual outcome. IV. The effectiveness of clinical parameters and IL-1 genotype in accurately predicting prognoses and tooth survival. Journal of Periodontology, Vol. 70, pp. 49-56, ISSN 0022-3492

Merchant, A.; Pitiphat, W.; Douglass, CW. ; Crohin, C. \& Joshipura, K. (2002). Oral hygiene practices and periodontitis in health care professionals. Journal of Periodontology, Vol.73, pp. 531-535, ISSN 0022-3492

Michalowicz, BS.; Diehl, SR \& Gunsolley, JC. (2000). Evidence of a substantial genetic basis for risk of adult periodontitis. Journal of Clinical Periodontology, Vol.71, pp. 16991707, ISSN 0303-6979

Morris, AL.; Steele, J. \& White, DA. (2001). The oral cleanliness and periodontal health of UK adults in 1998. Brittish Dental Journal, Vol. 191, No.4, pp. 186-192, ISSN 0007-0610

Noack, b.; Gorgens, h \& Hoffmann, T. (2004). Novel mutations in the cathepsin C gene in patients with pre-pubertal aggressive periodontitis and Papillon-Lefevre syndrome. Journal of Dental Research, Vol.83, No.5, pp. 368-370, ISSN 0022-0345

Nishida, N.; Tanaka, M \& Hayashi, N. (2005). Determination of smoking and obesity as periodontitis risks using the classification and regression tree method. Journal of Periodontology, Vol.76, pp. 923-928, ISSN 0022-3492

O'Brien, m. (1994). Children's dental health in the United Kingdom, HMSO, London

Offenbacher, S.; Collins, JG.; Yalda, B. \& Haradon, G. (1986). Periodontal health and periodontal disease in young people: global epidemiology. International Dental Journal, Vol.36, pp. 146-151, ISSN 0020-6539

Offenbacher, S.; Katz, V. \& Fertik, G. (1996). Periodontal infection as a risk factor for preterm low birth weight. Journal of Periodontology, Vol.67, pp. 72-77, ISSN 0022-3492

Okamoto, H.; Yoneyama, T; Lindhe, J.; Haffajee, A. \& Socransky, S. (1990). Methods of evaluating periodontal disease data in epidemiological research. Journal of Clinical Periodontology, Vol.15, pp. 430-439, ISSN 0303-6979

Page, RC. (1992). Host response tests for diagnosing periodontal diseases. Journal of Periodontology, Vol.63, (Suppl.), pp. 356-366, ISSN 0022-3492

Page, RC.; Krall, EA.; Martin, J.; Mancl, L. \& Garcia, RI. (2002). Validity and accuracy of a risk calculator in predicting periodontal disease.. Journal of the American Dental Association, Vol. 133, pp. 569-576, ISSN 0002-8177 
Parkhill, JM.; Hennig, BJ.; Chapple, IL; Heasman, PA \& Taylor, JJ. (2000). Association of interleukin-1 gene polymorphisms with early-onset periodontitis. Journal of Clinical Periodontology, Vol.27, pp. 682-689, ISSN 0303-6979

Peretz, B.; Machtei, EE. \& Bimstein, E. (1993). Changes in periodontal status of children and young adolescents: A one year longitudinal study. Journal of Clinical Paediatric Dentistry, Vol.18 pp. 3-6, ISSN 1053-4628

Persson, RE.; Persson, GR; Kiyak, HA. \& Powell, LV. (1998). Powell LV. Oral

health and medical status in dentate low-income older persons. Special Care Dentistry, Vol. 18, pp. 70-71, ISSN 0275-1879

Pistorius, A.; Krahwinkel, T; Willerhausen, B. \& Bockstegen, C. (2002). Relationship between stress factors and periodontal disease. European Journal of Medical Research, Vol.7, pp. 393-398, ISSN 0949-2321

Poulton, R.; Caspi, A. \& Milne, BJ. (2002). Association between children's experience of socioeconomic disadvantage and adult health: a life-course study. Lancet, Vol. 360, No.9346 pp. 1640-1645, ISSN 0140-6736

Ramfjord, SP. (1959). Indices for prevalence and incidence of periodontal disease. Journal of Periodontology, Vol. 30, pp. 51-59, ISSN 0022-3492

Reichert, S.; Stein, SA. \& Gautsch, A. (2002). Gender differences in HLA phenotype frequencies found in German patients with generalized aggressive periodontitis and chronic periodontitis. Oral Microbiology and Immunology, Vol.17, No.6, pp. 360368, ISSN 0902-0055

Russell, AL. (1967). Epidemiology of periodontal disease. International Dental Journal, Vol.17, pp. 282-296, ISSN 0020-6539

Saito, T.; Shimazaki, Y \& Sakamoto, M. (1998). Obesity and periodontitis. New England Journal of Medicine, Vol. 339, pp. 482-483, ISSN 0028-4793

Saito, T.; Shimazaki, Y \& Yamashita, Y. (1999). Association between periodontitis and exercise capacity. Periodontol insights, Vol.6, pp. 9-12, ISSN 1195-2008

Saito, T.; Shimazaki, Y; Hideshima, A.; Tsuzuki, M. \& Koga, T. (2000). Body mass index, abdominal adiposity and blood pressure: Relationship between upper body obesity and periodontitis. Journal of Dental Research, Vol.79 (abstract), pp. 625, ISSN 00220345

Saito, T.; Shimazaki, Y; Koga, T.; Tsuzuki, M. \& Ohshima, A. (2001). Relationship between upper body obesity and periodontitis. Journal of Dental Research, Vol.80, pp. 16311636, ISSN 0022-0345

Sakellari, D.; Belibasakis, G; Chadjipadelis, T.; Arapostathis, K. \& Konstantinidis, A. (2001). Supragingival and subgingival microbiota of adult patients with Down's syndrome. Changes after periodontal treatment. Oral Microbiology and Immunology, Vol.16, pp. 376-382, ISSN 0902-0055

Schou, L. \& Wight, C. (1994). Does dental health education affect inequalities in dental health? Community Dental Health, Vol.11, pp. 97-100, ISSN 0265-539X

Sheiham, A. \& Netuveli, GS. (2002). Periodontal diseases in Europe. Periodontology 2000, Vol.29, pp. 104-121, ISSN 0906-6713

Shuldiner, A.; Yang, R \& Gong, D. (2001). Resistin, obesity and insulin resistance-the emerging role of the adipocytes as an endocrine organ. New England journal of medicine, Vol. 345, pp. 1345-1346, ISSN 0028-4793 
Susin, C.; Oppermann, RV. \& Haugejorden, O. (2004). Periodontal attachment loss attributable to cigarette smoking in an urban Brazilian population. Journal Clinical Periodontology, Vol.31, pp. 951-959, ISSN 0303-6979

Tervonen, T.; Oliver, RC.; Wolff, LF.; Bereuter, J.; Anderson, L. \& Aeppli, DM. (1994). Prevalence of periodontal pathogens with varying metabolic control of diabetes mellitus. Journal of Clinical Periodontology, Vol.21, pp. 375-379, ISSN 0303-6979

Tervonen, T. \& Karjalainen K . (1997). Periodontal disease related to diabetic status. A pilot study of the response to periodontal therapy in type 1 diabetes. Journal of Clinical Periodontology, Vol. 24, pp. 505-510, ISSN 0303-6979

Thomas, E.; Van Dyke, DDS. \& Sheilesh, D (2005). Risk factors for periodontitis. Journal of the International Academy of Periodontology, Vol.7 (January), pp. 3-7, ISSN 1466-2094

Thomson, WM. \& Locker, D. (2000). Dental neglect and dental health among 26-year-olds in the Dunedin Multidisciplinary Health and Development Study. Community Dentistry and Oral Epidemiology, Vol.28, pp. 414-418, ISSN 0301- 5661

Thomson, WM.; Edwards, SJ. \& Dobson-Le, DP. (2001). IL-1 genotype and adult periodontitis among young New Zealanders. Journal of Dental Research, Vol.80, pp. 1700-1703, ISSN 0022-0345

Timmerman, MF.; Van der Weijden, GA. \& Abbas, F. (2000). Untreated periodontal disease in Indonesian adolescents. Longitudinal clinical data and prospective clinical and microbiological risk assessment. Journal of Clinical Periodontology, Vol. 27, pp. 932942, ISSN 0303-6979

Timmerman, MF.; Van der Weijden, GA. \& Arief, EM. (2001). Untreated periodontal disease in Indonesian adolescents. Subgingival microbiota in relation to experienced progression of periodontitis. Journal of Clinical Periodontology, Vol. 28, pp. 617-627, ISSN 0303-6979

Tomar, SL. \& Asma, S (2000). Smoking-attributable periodontitis in the United States: findings from NHANES III. National Health and Nutrition Examination Survey. Journal of Periodontology, Vol.71, No.5,, pp. 743-751, ISSN 0022-3492

Tran, SD.; Rudney, JD.; Sparks, BS. \& Hodges, JS. (2001). Persistent presence of Bacteroides forsythus as a risk factor for attachment loss in a population with low prevalence and severity of adult periodontitis. Journal of Periodontology, Vol. 72, pp. 1-10, ISSN 0022-3492

Tsai, C.; Hayes, C. \& Taylor, GW. (2002). Glycemic control of type 2 diabetes and severe periodontal disease in the US adult population. Community Dentistry and Oral Epidemiology, Vol.301, pp. 182-192, ISSN 0301- 5661

Umino, M. \& Nagao, M. (1993). Systemic diseases in elderly dental patients. International Dental Journal, Vol.43, pp. 213-218, ISSN 0020-6539

Westfelt, E.; Rylander, H; Blohme, G.; Jonasson, P. \& Lindhe, J. (1996). The effect of periodontal therapy in diabetics. Results after 5 years. Journal of Clinical Periodontology, Vol.23, pp. 92-100, ISSN 0303-6979

Wimmer, G.; Janda, M; Wieselmann-Penkner, K. \& Pertl, C. (2002). Coping with stress: its influence on periodontal disease. Journal of Periodontology, Vol.73, pp. 1343-1351, ISSN 0022-3492

Wolff, L.; Dahlen, G. \& Aeppli, D. (1994). Bacteria as risk markers for periodontitis. Journal of Periodontology, Vol.65, No.5, pp. 498-510, ISSN 0022-3492 
Wood, N.; Johnson, R \& Streckfus, F. (2003). Comparison of body composition and periodontal disease using nutritional assessment techniques. Journal of Clinical Periodontology, Vol.30, pp. 321-327, ISSN 0303-6979 


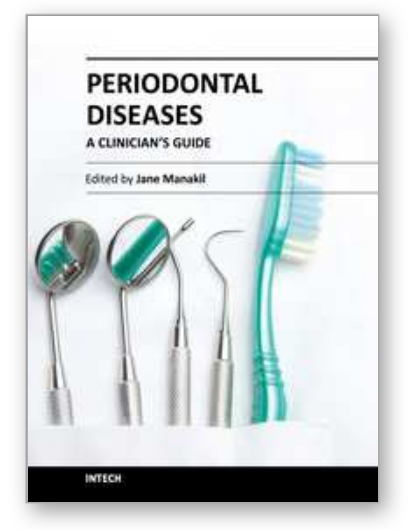

\author{
Periodontal Diseases - A Clinician's Guide \\ Edited by Dr. Jane Manakil
}

ISBN 978-953-307-818-2

Hard cover, 368 pages

Publisher InTech

Published online 03, February, 2012

Published in print edition February, 2012

"Periodontal diseases" is a web-based resource intended to reach the contemporary practitioners as well as educators and students in the field of periodontology. It is fully searchable and designed to enhance the learning experience. Within the book a description is presented of the current concepts presenting the complex interactions of microbial fingerprint, multiple genotypes, and host modulations. In addition, an overview is given of the clinical outcome of the disease's progression, as influenced by the epigenetic factors. Emerging concepts on periodontitis as a risk factor for various systemic diseases and as a bilateral modulating factor have been elucidated in detail as well.

\title{
How to reference
}

In order to correctly reference this scholarly work, feel free to copy and paste the following:

Amin E. Hatem (2012). Epidemiology and Risk Factors of Periodontal Disease, Periodontal Diseases - A Clinician's Guide, Dr. Jane Manakil (Ed.), ISBN: 978-953-307-818-2, InTech, Available from: http://www.intechopen.com/books/periodontal-diseases-a-clinician-s-guide/epidemiology-and-risk-factors-ofperiodontal-disease

\section{INTECH}

open science | open minds

\section{InTech Europe}

University Campus STeP Ri Slavka Krautzeka 83/A 51000 Rijeka, Croatia Phone: +385 (51) 770447

Fax: +385 (51) 686166 www.intechopen.com

\section{InTech China}

Unit 405, Office Block, Hotel Equatorial Shanghai No.65, Yan An Road (West), Shanghai, 200040, China 中国上海市延安西路65号上海国际贵都大饭店办公楼 405 单元 Phone: +86-21-62489820

Fax: +86-21-62489821 
(C) 2012 The Author(s). Licensee IntechOpen. This is an open access article distributed under the terms of the Creative Commons Attribution 3.0 License, which permits unrestricted use, distribution, and reproduction in any medium, provided the original work is properly cited. 